\title{
2 Characterization of thirty two microsatellite loci for three 3 Atlanto-Mediterranean echinoderm species
}

\author{
4 Alex Garcia-Cisneros • Claudio Valero-Jiménez • \\ 5 Creu Palacín - Rocío Pérez-Portela
}

6 Received: 29 January 2013/ Accepted: 22 February 2013

7 (C) Springer Science+Business Media Dordrecht 2013

8 Abstract Thirty two microsatellites were optimized from 9454 pyrosequencing libraries for three Atlanto-Mediterra10 nean echinoderms: Coscinasterias tenuispina, Echinaster 11 sepositus and Arbacia lixula. We observed different frequency of microsatellite types (di-, tri-, tetra- and pentanucleotide) throughout the genome of the species, but no significant differences were observed in allele richness among different microsatellite repeats. No loci showed linkage disequilibrium. Heterozygosity deficit and departure from Hardy-Weinberg equilibrium were observed for some loci, in two species, probably due to high levels of inbreeding. Heterozygosity excess observed in $C$. tenuispina could be explained by selection against homozygotes and/or outcrossing.

Keywords Pyrosequencing · Inbreeding · Clonality Conservation - Starfish $\cdot$ Sea urchin

Electronic supplementary material The online version of this article (doi:10.1007/s12686-013-9897-5) contains supplementary material, which is available to authorized users.

A. Garcia-Cisneros · C. Valero-Jiménez · C. Palacín Department of Animal Biology (Invertebrates), University of Barcelona, 643 Diagonal Avenue, 08028 Barcelona, Spain

Present Address:

C. Valero-Jiménez

Wageningen University, Wageningen, The Netherlands

C. Palacín

Biodiversity Research Institute (IRBIO), Barcelona, Spain

R. Pérez-Portela $(\square)$

Center for Advanced studies of Blanes (CEAB-CSIC), Acesso

a la Cala Sant Francesc 14, Blanes, 17300 Girona, Spain

e-mail: perezportela@gmail.com
During last century, Mediterranean Sea has suffered an extensive loss of biodiversity due to high anthropogenic pressures and environmental perturbations (Coll et al. 2010). Introduction of non-native species, increase in water temperature and extensive gaps in the distribution of natural populations due to urbanization, are among the most important environmental pressures (Thibaut et al. 2005; Lejeusne et al. 2010).

In this study we described new microsatellite loci for three of the most common Atlanto-Mediterranean echinoderms with important implications for conservation; the starfishes Echinaster sepositus and Coscinasterias tenuispina, and the sea urchin Arbacia lixula. E. sepositus is an emblematic species along the Atlanto-Mediterranean area but some populations at the North-Western Mediterranean have suffered a severe decline (Villamor and Becerro 2010; authors' pers. obs.). This species is now scarce in areas with high anthropogenic pressure and affluence of divers, and larger populations are only observed within marine protected areas. Due to the short-distance dispersal of its lecithotrophic larva, studies about populations' connectivity, inbreeding and genetic structure are crucial to design future management strategies for restoring their populations (Jones et al. 2007).

On the other hand, mitochondrial data suggested a recent colonization of the Mediterranean from the Atlantic Ocean by the thermophilous species A. lixula and C. tenuispina (Wangensteen et al. 2012; authors' unpublished data), and whose densities may increase dramatically in the foreseeable future. Global warming might facilitate population blooms and thus turn these species into an ecological problem. Both species can modify sublittoral habitats because of their voracity generating barren grounds when populations reach high densities (Guidetti et al. 2003; Bonaviri et al. 2011). Populations' monitoring, including

\begin{tabular}{lll} 
Journal : Large 12686 & Dispatch : $\mathbf{2 5 - 2 - 2 0 1 3}$ & Pages : $\mathbf{5}$ \\
Article No. : $\mathbf{9 8 9 7}$ & $\square$ LE & $\square$ TYPESET \\
MS Code : COGR-D-13-00040 & $\boldsymbol{\sim}_{\mathrm{CP}}$ & $\boldsymbol{\sim}$ DISK \\
\hline
\end{tabular}




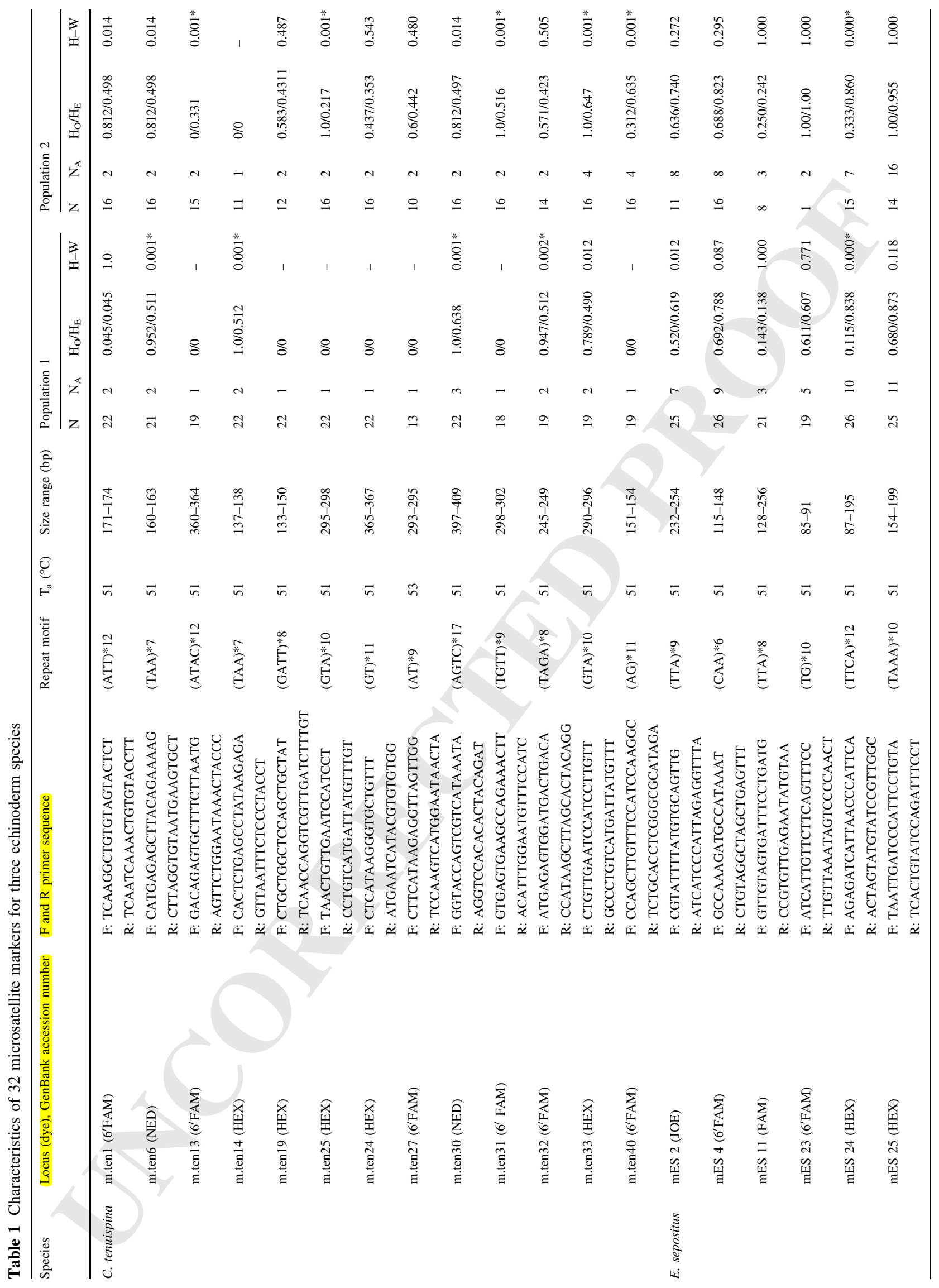

\begin{tabular}{|l|lll|}
\hline & Journal : Large 12686 & Dispatch : 25-2-2013 & Pages : $\mathbf{5}$ \\
& Article No. : $\mathbf{9 8 9 7}$ & $\square \mathrm{LE}$ & $\square$ \\
MS Code : COGR-D-13-00040 & $\checkmark_{\mathrm{CP}}^{\mathrm{TYPESET}}$ \\
\hline
\end{tabular}




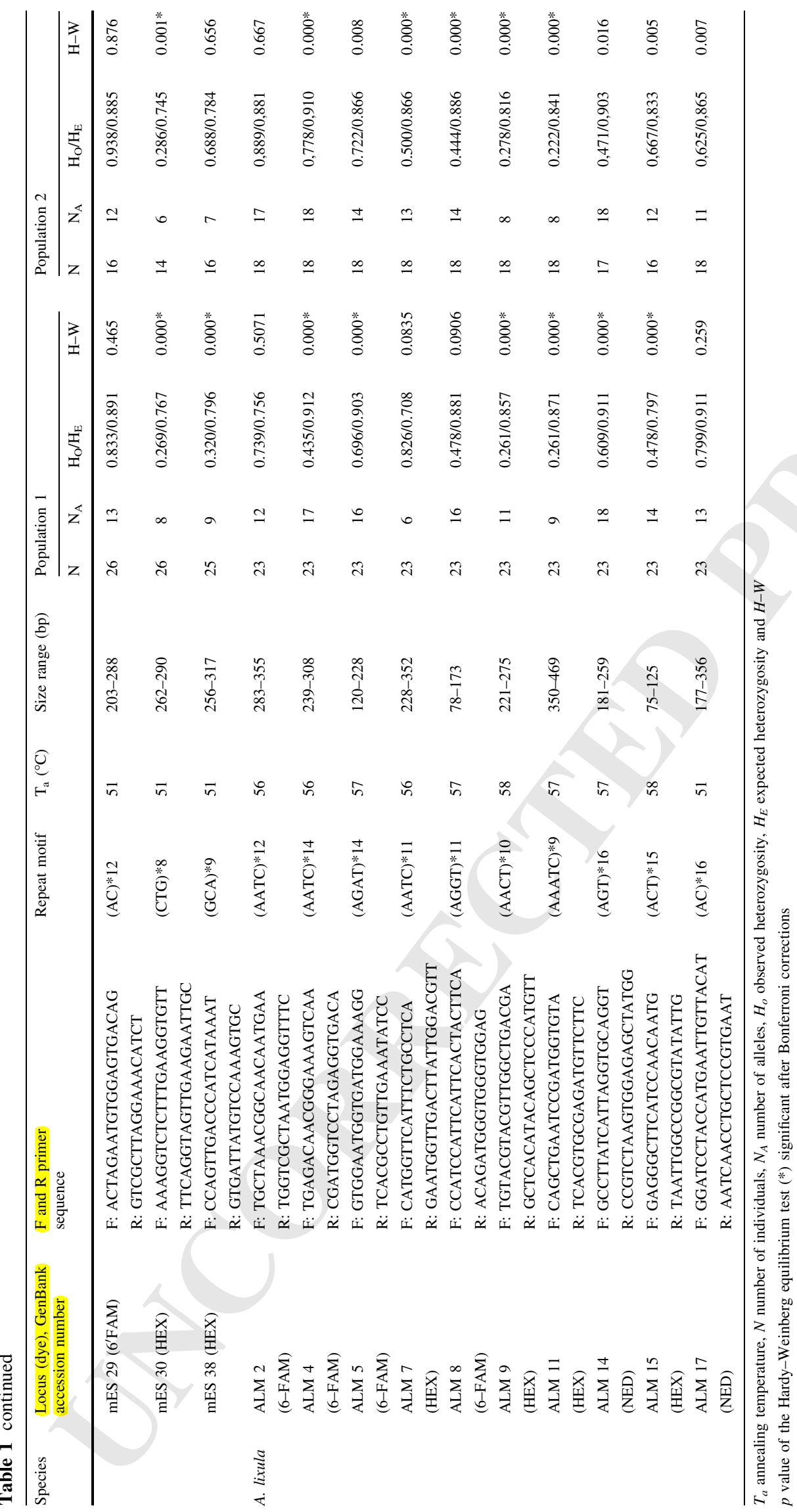

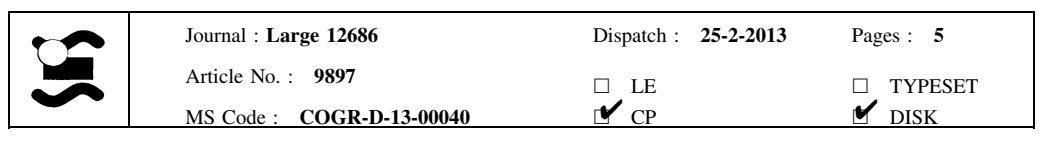


recruitment and connectivity studies between Atlantic sources and Mediterranean stocks based on microsatellites, is highly recommendable to evaluate the potential threat of these species for Mediterranean ecosystems.

We used 454 pyrosequencing to isolate novel microsatellite loci in C. tenuispina, E. sepositus and A. lixula. Genomic DNA was extracted using QIAamp ${ }^{\circledR}$ DNA Mini Kit (QIAGEN) to a final DNA concentration of $5 \mathrm{ng} / \mu \mathrm{l}$ and distributed in three physically separated lanes of a plate. Pyrosequencing was performed on a Roche Life Science 454 GS-FLX System at the Scientific-Technical Services of University of Barcelona. Sequences were trimmed to remove regions with a greater than $0.5 \%$ chance of error per base using GENEIOUS version 5.5 (Drummond et al. 2011). Total number of sequences which passed quality filtering, number of microsatellites detected, and reads mode length were variable between species, and all details are summarized in Online Resource 1. Sequences were searched for perfect microsatellites (di-, tri-, tetra- and pentanucleotides) with at least eight repeats and enough priming regions with QDD1 v. 1.3 (Meglécz et al. 2010). Primers were designed with the software PRIMER 3 (Rozen and Skaletsky 2000).

Amplification success and polymorphism were tested in two populations per species: Costa Brava $\left(42^{\circ} 29^{\prime} \mathrm{N}\right.$, $\left.3^{\circ} 10^{\prime} \mathrm{E}\right)$ and Tenerife $\left(28^{\circ} 25^{\prime} \mathrm{N}, 16^{\circ} 19^{\prime} \mathrm{W}\right)$ in C. tenuispina, Costa Brava $\left(41^{\circ} 46^{\prime} \mathrm{N}, 3^{\circ} 05^{\prime} \mathrm{E}\right)$ and Marseille $\left(43^{\circ} 16^{\prime} \mathrm{N}\right.$, $\left.49^{\circ} 34^{\prime} \mathrm{E}\right)$ for E. sepositus, and Costa del Sol $\left(36^{\circ} 34^{\prime} \mathrm{N}\right.$, $\left.4^{\circ} 34^{\prime} \mathrm{W}\right)$ and Costa Brava $\left(42^{\circ} 24^{\prime} \mathrm{N}, 3^{\circ} 07^{\prime} \mathrm{E}\right)$ in A. lixula. Total DNA was extracted from feet tube and amplified using the REDExtract-N-Amp Tissue PCR Kit (Sigma Aldrich). Forward primers were labelled with a fluorescent dye as shown in Table 1. PCR amplifications were performed as described in Valero-Jiménez et al. (2012). Allele length was estimated relative to the internal size standard 70-500 ROX (Bioventures) using the software Peak-Scanner (Applied Biosystems).

Dinucleotides were the most frequent microsatellites followed by tri, tetra and pentanucleotides throughout the genome of the species (see Online Resource 2). A total of thirteen, nine and ten polymorphic microsatellite were optimized for C. tenuispina, E. sepositus and A. lixula, respectively, including a selection of different microsatellite types (see Table 1). Linkage disequilibrium, observed and expected heterozygosity, and deviation from HardyWeinberg equilibrium were calculated with ARLEQUIN v3.5.1.2 (Excoffier and Lischer 2010). Bonferroni corrections of the $p$ values for multiple tests were run.

No evidence of linkage disequilibrium was detected across all pairwise comparisons. Failed amplifications due to presence of null alleles were not detected for any loci. Nineteen markers showed Hardy-Weinberg disequilibrium after Bonferroni corrections. Heterozygosity deficit observed in two species may be explained by high levels of inbreeding, as demonstrated in other marine invertebrates (Pérez-Portela and Turon 2008; Calderón et al. 2009). The heterozygosity excess observed in C. tenuispina may be explained by clonal reproduction, selection against homozygotes and/or outcrossing (Blanquer and Uriz 2010). After confirming normality and homoscedasticity of the dependent variable, we used a twoway $_{\Lambda}$ ANOVA to test for differences in genetic diversity (measured as allelic richness) of different microsatellite types and species. Genetic diversity values were adjusted to population size with a rarefaction index calculated in CONTRIB V1.2 (Petit et al. 1998). Our results did not show differences in genetic diversity among di, tri, tetra and pentanucleotide repeats $(\mathrm{F}=0.233 ; p=0.872)$ but diversity was significantly different among species $(\mathrm{F}=35.69 ; p<0.0001)$ (see Online Resource 3 ). This result suggests that different microsatellite types are equally valid in terms of genetic diversity to assess population genetics in echinoderm species.

Acknowledgments This research was supported by a predoctoral FPI-MICINN fellowship to A.G.C (BES-2011-044154), the Spanish Government project CTM2010-22218-C02-02 and the European project 287844-COCONET (FP7/2007-2013).

\section{References}

Addison IA, Hart MW (2002) Characterization of microsatellite loci in sea urchins (Strongylocentrotus spp.). Mol Ecol Notes 2:493-494

Blanquer A, Uriz MJ (2010) Population genetics at three spatial scales of a rare sponge living in fragmented habitats. BMC Evol Biol 10:13

Bonaviri C, Vega Fernández T, Fanelli G, Badalamenti F, Gianguzza P (2011) Leading role of the sea urchin Arbacia lixula in maintaining the barren state in southwestern Mediterranean. Mar Biol 158:2505-2513

Calderón I, Turon X, Pascual M (2009) Isolation of nine nuclear microsatellites in the common Mediterranean sea urchin, Paracentrotus lividus (Lamarck). Mol Ecol Resour 4:1145-1147

Coll M, Piroddi C, Steenbeek J, Kaschner K, Lasram FBR, Aguzzi J, Ballesteros E, Bianchi CN, Corbera J, Dailianis T, Danovaro R, Estrada M, Froglia C, Galil BS, Gasol JM, Gertwagen R, Gil J, Guilhaumon F, Kesner-Reyes K, Kitsos M-S, Koukouras A, Lampadariou N, Laxamana E, López-Fé de la Cuadra CM, Lotze HK, Martin D, Mouillot D, Oro D, Raicevich S, Rius-Barile J, Saiz-Salinas JI, San Vicente C, Somot S, Templado J, Turon X, Vafidis D, Villanueva R, Voultsiadou E (2010) The biodiversity of the Mediterranean Sea: estimates, patterns, and threats. PLoS ONE 5:e11842

Drummond AJ, Ashton B, Buxton S, Cheung M, Cooper A, Duran C, Field M, Heled J, Kearse M, Markowitz S, Moir R, Stones-Havas S, Sturrock S, Thierer T, Wilson A (2011) Geneious v5.4, Available from http://www.geneious.com

Excoffier L, Lischer HE (2010) Arlequin suite ver 3.5: a new series of programs to perform population genetics analyses under Linux and Windows. Mol Ecol Resour 10:564-567

Guidetti P, Fraschetti S, Terlizzi A, Boero F (2003) Distribution patterns of sea urchins and barrens in shallow Mediterranean

\begin{tabular}{|l|lll|}
\hline & Journal : Large 12686 & Dispatch : 25-2-2013 & Pages : $\mathbf{5}$ \\
Article No. : 9897 & $\square$ & LE & $\square$ TYPESET \\
MS Code : COGR-D-13-00040 & $\sim_{\mathrm{CP}}$ & $\boldsymbol{\sim}$ DISK \\
\hline
\end{tabular}


rocky reefs impacted by the illegal fishery of the rock-boring mollusc Lithophaga lithophaga. Mar Biol 143:1135-1142

Jones PG, Srinivasan M, Almany RG (2007) Population connectivity and conservation of marine biodiversity. Oceanography 20:100-111

Lejeusne C, Chevaldonné P, Pergent-Martini C, Boudouresque CF, Pérez T (2010) Climate change effects on a miniature ocean: the highly diverse, highly impacted Mediterranean Sea. Trends Ecol Evol 25:250-260

Meglécz E, Costedoat C, Dubut V, Gilles A, Malausa T, Pech N, Martin J-F (2010) QDD: a user-friendly program to select microsatellite markers and design primers from large sequencing projects. J Bioinf 26:403-414

Pérez-Portela R, Turon X (2008) Cryptic divergence and strong population structure in the colonial invertebrate Pycnoclavella communis (Ascidiacea) inferred from molecular data. Zoology 111:163-178

Petit RJ, El Mousadik A, Ponst O (1998) Identifying basis of populations markers for conservation on the basis of genetic markers. Conserv Biol 12:844-855
Rozen S, Skaletsky H (2000) Primer3 on the WWW for general users and for biologist programmers. Methods Mol Biol 132:365-386

Thibaut T, Pinedo S, Torras X, Ballesteros E (2005) Long-term decline of the populations of Fucales (Cystoseira spp. and Sargassum spp.) in the Albères coast (France, North-western Mediterranean). Mar Pollut Bull 50:1472-1489

Valero-Jiménez C, Pérez-Portela R, López-Legentil S (2012) Characterization of novel microsatellite markers from the worldwide invasive ascidian Styela plicata. Conserv Genet Resour 4: $559-561$

Villamor A, Becerro MA (2010) Matching spatial distributions of the sea star Echinaster sepositus and crustose coralline algae in shallow rocky Mediterranean communities. Mar Biol 157: 2241-2251

Wangensteen OS, Turon X, Pérez-Portela R, Palacín C (2012) Natural or naturalized? Phylogeography suggests that the abundant sea urchin Arbacia lixula is a recent colonizer of the Mediterranean. PLoS ONE 7:e45067

\begin{tabular}{|l|lll|}
\hline & Journal : Large 12686 & Dispatch : 25-2-2013 & Pages : $\mathbf{5}$ \\
Article No. : $\mathbf{9 8 9 7}$ & $\square$ LE & $\square$ TYPESET \\
MS Code : COGR-D-13-00040 & $\sim_{\text {CP }}$ & $\checkmark$ DISK \\
\hline
\end{tabular}

